\title{
Estimation of Rainfall Erosivity Index for Auchi, Edo State, Using Lombardi's Method
}

\author{
Ajayi A. S. ${ }^{1} \quad$ Ehiomogue P. $^{2} \quad$ Kayong A. E. $^{3} \quad$ Duweni E. C. ${ }^{4}$ \\ 1.Department of Agricultural and Bio-Environmental Engineering Technology, Auchi Polytechnic Auchi \\ 2.Department of Agricultural Engineering, Michael Okpara University of Agriculture, Umudike, Abia State \\ Nigeria \\ 3.Department of Agricultural and Bio-Environmental Engineering, Samaru-Kataf Campus Nuhu Bamalli \\ Polytechnic Zaria-Nigeria \\ 4.Department of Civil Engineering, University of Ibadan, Oyo State Nigeria
}

\begin{abstract}
The erosivity factor in the universal soil loss equation (USLE) provides an effective means of evaluating the erosivity power of rainfall. This study evaluated the erosivity factor based on monthly and annual precipitation rainfall data of Auchi, Edo State covering a period of $2005-2014$ using Lombardi method $\left(E I=1.03 \mathrm{~V}_{\mathrm{d}}{ }^{1.51}\right)$. It was discovered that higher rainfall values resulted in high erosivity index values which was in line with other tropical climates. The average annual erosivity index for the city during the period of study was $587.32 \mathrm{MJ}$ $\mathrm{mm} / \mathrm{hr}$. The $\mathrm{R}^{2}$ of 0.651 shows that precipitation alone contributed $65.1 \%$ of the erosion risk within the study period. The knowledge of impact of rainfall on erosivity is essential in soil erosion risk assessment and for soil and water conservation planning.
\end{abstract}

Keywords: Erosivity, Kinetic energy, Erosion, Rainfall intensity, Lombardi, Erodibility, Auchi, Soil loss DOI: $10.7176 / \mathrm{CER} / 11-1-02$

\subsection{INTRODUCTION}

Soil loss is closely related to rainfall partly through the detaching power of raindrops striking the soil surface and partly through the contribution of rain to runoff. This applies particularly to erosion by overland flow and rills, for which intensity is generally considered to be the most important rainfall characteristic (Morgan, 1942). Soil degradation resulting from erosion by storm water is perceived as one of the main climate-related problems worldwide since it has large environmental and economic impacts, especially in agricultural areas (Isikwe et al., 2015; Angulo-Mart ńez and Beguer á, 2009).

One of the most important factors in soil erosion by water is the erosive potential of raindrop impact. The rainfall erosivity factor (R) in the Universal Soil Loss Equation (USLE) is generally recognized as one of the best parameters for the prediction of the erosive potential of raindrop impact (Loureiro and Coutinho 2001). Various properties of raindrops, such as intensity, velocity, size, and kinetic energy, are among the most frequently used parameters to develop erosivity indices. The $\mathrm{A}_{\mathrm{r}} \mathrm{I}_{\mathrm{m}}$ (rainfall amount $\times$ maximum intensity), $\mathrm{EI}_{30}$ (rainfall energy $\times$ maximum 30-min intensity), and $\mathrm{KE}>1$ (total kinetic energy of all of the rain falling at more than $25 \mathrm{~mm} \mathrm{~h}^{-1}$ ) are the most important rainfall erosivity indices. These 3 indices were developed by Lal, Wischmeier and Smith, and Hudson (Isikwe et al., 2015; Yu, 1998).

A direct computation of rainfall erosivity factors requires long-term data for both the amount and intensity of rainfall. In such a situation, more readily available types of parameters (rainfall amount-based indices) such as monthly or annual rainfall data could be utilized to predict rainfall erosivity indices. This makes it possible to adopt the correct strategies for soil conservation. Factors affecting the rate of soil erosion are rainfall, runoff, wind, soil, slope, plant cover and the presence or absence of conservation measures (Morgan, 1979).

Rainfall erosivity is the potential ability of rainfall to cause soil loss (Silva, 2004). The rainfall erosivity index represents the climate influence on water related soil erosion (Isikwe et al., 2015).

Erosion is seen as a multiplier of rainfall erosivity (the R factor, which equals the potential energy); this multiplies the resistance of the environment, which comprises K (soil erodibility), SL (the topographical factor), $\mathrm{C}$ (plant cover and farming techniques) and $\mathrm{P}$ (erosion control practices). Since it is a multiplier, if one factor tends toward zero, erosion will tend toward zero. This erosion prediction equation is composed of five subequations, and is given as:

$$
A=R . K . L . S . C . P
$$

Where, $\mathrm{A}$ is the average annual soil loss $\left(\mathrm{Mg} \mathrm{ha}^{-1} \mathrm{yr}^{-1}\right) ; \mathrm{R}$ is the rainfall erosivity index; $\mathrm{K}$ is the soil erodibility factor; $\mathrm{L}$ is the slope length factor; $\mathrm{S}$ is the slope gradient factor; $\mathrm{C}$ is the vegetation cover factor, and $\mathrm{P}$ Is the conservation protection factor. Each intensity has a corresponding kinetic energy, according to the Eq. 2, (Wichmeier and Smith, 1978). 


$$
\mathrm{KE}=11.87+8.73 \log _{10} \mathrm{I}
$$

Wischmeier's index, $\mathrm{EI}_{30}=\mathrm{KE} \times \mathrm{I}_{30}, \mathrm{KE}=$ kinetic energy of rainfall expressed in metric tons $\times \mathrm{m} / \mathrm{ha} / \mathrm{cm}$ of rainfall. $\mathrm{I}_{30}=$ is 30 minutes rainfall intensity in $\mathrm{mm} / \mathrm{hr}$. The intensity of rainfall is determined from the rainfall amount and duration using Eq. 3 below;

$$
I=\frac{\text { Rainfall Amount }}{\text { Change in Time }}
$$

Lombardi also related several USLE factor including rainfall erosivity and daily rainfall using Eq. 4;

$$
E I=1.03 V_{d}^{1.51}
$$

Where EI is the daily rainfall energy - intensity interaction or the erosivity index in $\mathrm{MJ} . \mathrm{mm} / \mathrm{hr}, \mathrm{V}_{\mathrm{d}}$ is the rainfall in $\mathrm{mm}$. method.

The objective of this study was to compute the rainfall erosivity index of Auchi, Edo state using Lombardi

\subsection{MATERIALS AND METHOD}

\subsection{Study Area}

Auchi is one of the fastest growing urban areas in Edo State. It is located between latitude $7^{0} 10^{\prime}$ and $7^{0} 20^{\prime}$ north of the equator and longitude $6^{0} 16^{\prime}$ and $6^{0} 36^{\prime}$ east of the Greenwich Meridian with an altitude of $207 \mathrm{~m}$. This area is made up of several quarters; they are Abotse, Ibie, Afadokhai, Usogun, Egeroso, Akpekpe, Iyekhei, Igbe, Iyetse and Afobomhe. This area experiences the humid tropical climate, which is characterized by wet and dry seasons. The topography is relatively undulating and it slopes from the north of the area to the south. The soil type is the loose sandy soil, which makes it susceptible to erosion (Onuoha, et al., 2012). Auchi gully erosion problem has become a source of worry to many people including traditional leaders in the area and Nigerians in general because of the economic and strategic importance of the town. So far, the menace has defied all palliative measures by the community, as the situation is continually getting worse. In the 2006 census, the study area had a population of 142,819 people. It has a total land area of $358 \mathrm{Km}^{2}$

\subsection{Data collection and handling}

The data used for this work were from secondary sources based on rainfall occurrence. The daily rainfall data used was from manual rain gauge and was obtained from the Auchi Polytechnic meteorological station, Edo State collected over a period of ten years $(2005$ - 2014). The erosivity index was determined using the Eq. 4. Average annual erosivity index for rainy months was found using the equation:

$$
\text { Average annual erosivity index }=\frac{5 u m \text { total of erosivity index for the rainy months }}{\text { Number of rainy months }}
$$

\subsection{RESULT AND DISCUSSION}

Erosivity index was estimated using Lombardi method, figures 1 and 2 show the combined plot representations of the monthly erosivity index from 2005 - 2014 and Figure 3 shows the combined plot of annual erosivity index and the annual precipitation values. For emphasis, Table 1a and b show the monthly, total and average erosivity index for the study area for 10 years. 
Table 1a: Monthly, Total and Average erosivity index from 2005 - 2009.

\begin{tabular}{rlrrrrr}
\hline S/N & Month & $\mathbf{2 0 0 5}$ & $\mathbf{2 0 0 6}$ & $\mathbf{2 0 0 7}$ & $\mathbf{2 0 0 8}$ & $\mathbf{2 0 0 9}$ \\
\hline 1 & Jan & 1.90 & 1.19 & 2.93 & 0.00 & 0.00 \\
2 & Feb & 80.97 & 8.36 & 15.41 & 43.89 & 0.00 \\
3 & Mar & 19.45 & 0.00 & 511.31 & 0.00 & 0.00 \\
4 & Apr & 55.40 & 233.80 & 260.22 & 230.60 & 299.02 \\
5 & May & 79.81 & 270.57 & 495.32 & 185.79 & 286.86 \\
6 & Jun & 200.27 & 550.79 & 396.79 & 287.59 & 102.19 \\
7 & Jul & 486.21 & 966.60 & 555.73 & 803.40 & 374.81 \\
8 & Aug & 821.01 & 1456.27 & 413.52 & 843.84 & 1058.25 \\
9 & Sep & 202.95 & 549.75 & 554.95 & 117.23 & 188.22 \\
10 & Oct & 274.25 & 828.89 & 265.28 & 202.21 & 35.88 \\
11 & Nov & 543.28 & 0.00 & 0.00 & 0.00 & 0.00 \\
12 & Dec & 0.00 & 9.98 & 0.00 & 18.21 & 0.00 \\
\hline & Sum & 2765.49 & 4876.20 & 3471.47 & 2732.75 & 2345.22 \\
& Ave & 230.46 & 406.35 & 289.29 & 227.73 & 195.43
\end{tabular}

Source: Dept. of Civil Engineering Tech. meteorological station, Auchi Polytechnic Auchi

Table 1b: Monthly, Total and Average erosivity index from 2010 - 2014

\begin{tabular}{rlrrrrr}
\hline S/N & Month & $\mathbf{2 0 1 0}$ & $\mathbf{2 0 1 1}$ & $\mathbf{2 0 1 2}$ & $\mathbf{2 0 1 3}$ & $\mathbf{2 0 1 4}$ \\
\hline 1 & Jan & 0.88 & 0.00 & 0.00 & 0.00 & 1.36 \\
2 & Feb & 80.97 & 0.00 & 0.00 & 0.00 & 34.34 \\
3 & Mar & 93.14 & 57.20 & 322.99 & 0.00 & 217.19 \\
4 & Apr & 283.64 & 137.81 & 211.53 & 206.85 & 765.67 \\
5 & May & 265.28 & 270.36 & 183.99 & 173.34 & 1075.29 \\
6 & Jun & 229.24 & 213.41 & 157.78 & 329.51 & 565.39 \\
7 & Jul & 663.66 & 814.04 & 432.51 & 368.44 & 909.12 \\
8 & Aug & 550.79 & 322.99 & 113.41 & 234.48 & 1252.34 \\
9 & Sep & 200.27 & 183.99 & 249.22 & 205.92 & 940.04 \\
10 & Oct & 202.95 & 172.46 & 188.49 & 950.95 & 1191.19 \\
11 & Nov & 0.00 & 0.00 & 94.21 & 0.00 & 72.95 \\
12 & Dec & 24.25 & 0.00 & 33.33 & 0.00 & 22.90 \\
\hline & Sum & 2595.06 & 2172.27 & 1987.45 & 2469.49 & 7047.78 \\
& Ave & 216.25 & 181.02 & 165.62 & 205.79 & 587.32 \\
\hline
\end{tabular}

Source: Dept. of Civil Engineering Tech. meteorological station, Auchi Polytechnic Auchi

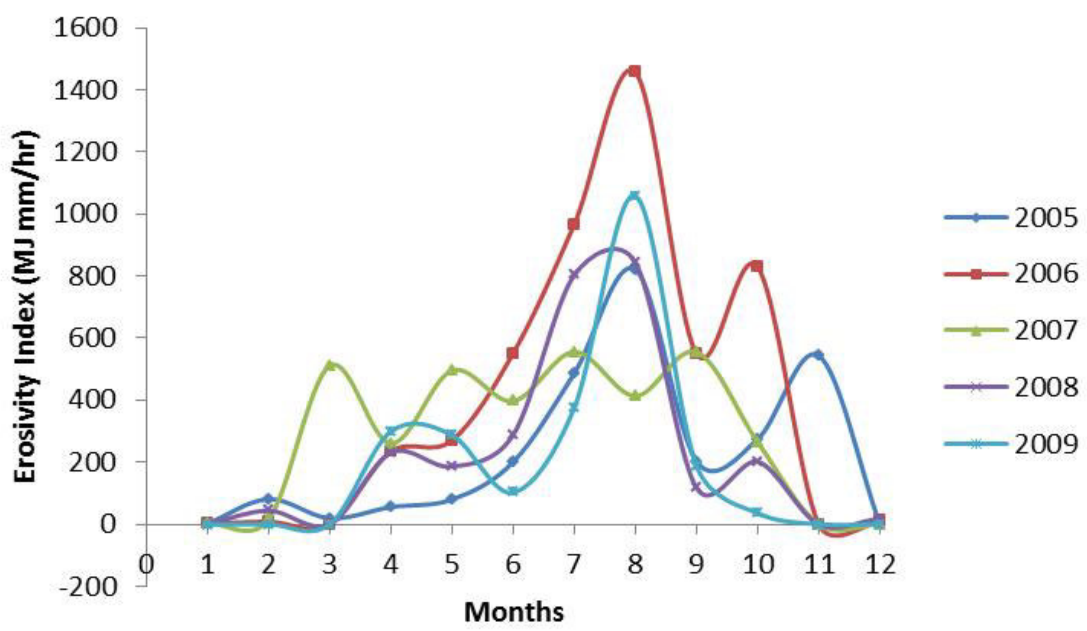

Figure 1: Monthly Variation of Erosivity Index for 2005 - 2009 


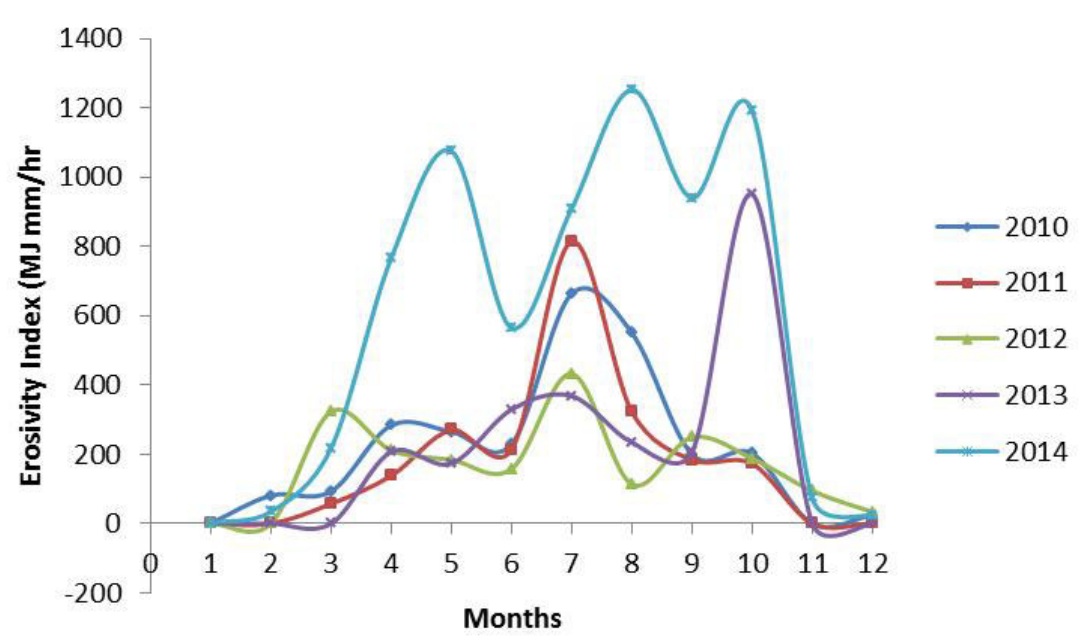

Figure 2: Monthly Variation of Erosivity Index for 2010- 2014

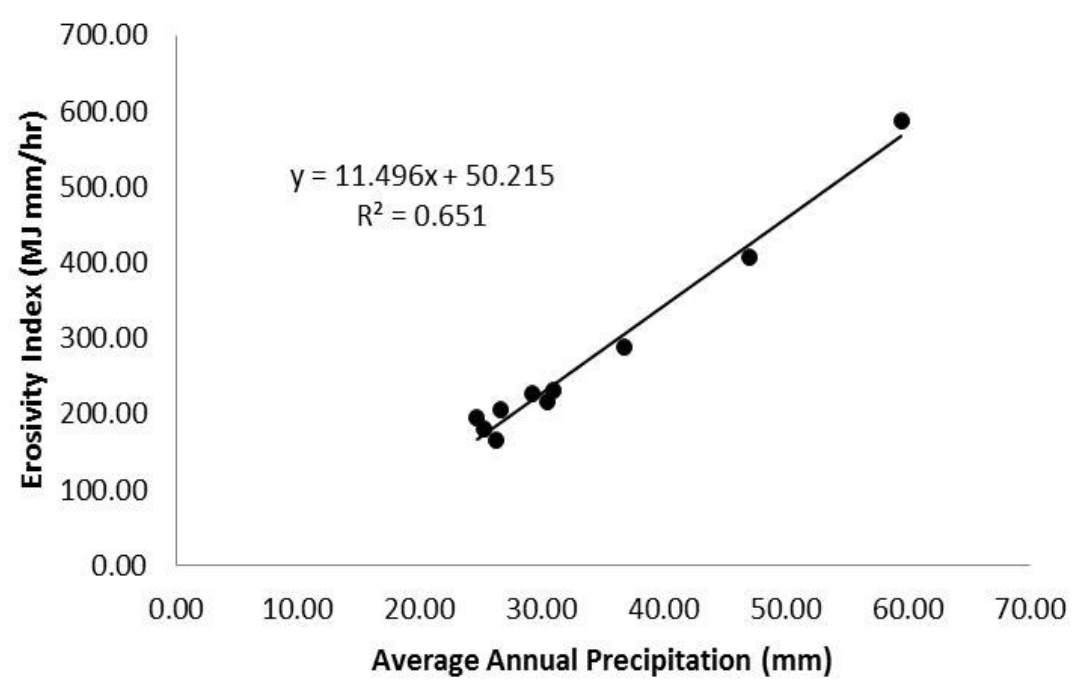

Figure 3: Correlation between annual erosivity index and average annual precipitation

From figures 1 and 2, the month of August has the highest erosivity index. The months with zero rainfall had zero KE and zero EI. As the years go by, the relationship between precipitation pattern and erosivity index becomes more pronounced, i.e higher the precipitation, the higher the erosivity index. This is confirmed by the finding of review of rainfall erosivity in Brazil by Oliveira et al., (2002), that higher erosivity values observed in the tropics are caused by the high amount of precipitation, intensity, and KE of rain. Also that the ranges of rainfall erosivity values in tropical regions are similar and they are higher than those observed in other temperate climate regions.

Figure 3 shows the correlation between annual erosivity index and average annual precipitation. The correlation between annual erosivity index and average annual precipitation was expressed as $\mathrm{Y}=11.496 \mathrm{x}+$ 50.215. The coefficient of Determination $\mathrm{R}^{2}$ of $0.651(65.1 \%)$ is an indication that precipitation alone contributed $65.1 \%$ of erosion hazard during the period of study. The remaining percentage could be explained by soil, conservation, management and anthropogenic factors. The increase in precipitation could be as a result of climate change.

\subsection{CONCLUSION}

The rainfall erosivity factor $(\mathrm{R})$ is one of the key factors in the USLE model and has gained increasing importance as the environmental effects of climate change have become more severe. The erosivity index for Auchi, was evaluated using Lombadi equation covering a period of 2005 - 2014. It was discovered that higher rainfall values resulted in high erosivity index values which was in line with other tropical climates. The average annual erosivity index for the city during the period of study was $587.32 \mathrm{MJ} \mathrm{mm} / \mathrm{hr}$. The $\mathrm{R}^{2}$ of 0.651 shows that precipitation alone contributed $65.1 \%$ of the erosion risk within the study period. The knowledge of impact of 
rainfall on erosivity is essential in soil erosion risk assessment and for soil and water conservation planning.

\section{REFERENCES}

Angulo-Mart ńez M. and Beguer á S. Estimating rainfall erosivity from daily precipitation records: a comparison among methods using data from the Ebro Basin (NE Spain). Journal of Hydrology 379 (1-2): 111-121 (2009).

Isikwue M. O., Ocheme E. and Aho M. I. (2015). Evaluation of rainfall erosivity index for Abuja, Nigeria using Lombardi method. Nigerian Journal of Technology (NIJOTECH) Vol. 34 No. 1, January 2015, pp. 56 - 63.

Loureiro N. and Coutinho M. (2001). A New Procedure to Estimate the RUSLE EI 30 Index Based on Monthly Rainfall Data and Applied to the Algarve Region, Portugal", Journal of Hydrology, Vol. 250: 2001, pp 1218.

Morgan, C. (1979). Field and Laboratory Examination of Soil Erosion as a Function of Erosivity and Erodibility for Selected Hillslope Soils from Southern Ontario. PhD Thesis, University of Toronto. 1979, 114pp.

Morgan, R. P. C. (1942). Soil Erosion and Conservation. - 3rd ed. Blackwell publishing

Oliveira, P.T., Wendland, E. Nearing, M.A. “ Rainfall Erosivity in Brazil: A review” Catena Vol. 100, 2002, pp $139-147$.

Onuoha S. N., F. I.Idike, Orakwe, L. C. (2012). Water Supply Resources for Domestic Purposes in Auchi metropolis of Edo State, Nigeria. International Journal of Engineering and Technology Volume 2 No. 6, June, 2012.

Silva, A.M. (2004). Rainfall Erosivity Map for Brazil. Catena.Vol. 57, 2004, pp 251-259. Wichmeier, W.H. Smith, D.D. Predicting Rainfall Losses-A Guide to Conservation Planning. USDA. 